\title{
Introduction to the Probable Movement of Thysanoptera through the Moravian Gate (Štramberk, Czech Republic)
}

\author{
W. SIERKA ${ }^{1 *}$, E. SIERKA ${ }^{2}$ and P. J. FEDOR ${ }^{3}$ \\ ${ }^{1}$ Department of Zoology, Faculty of Biology and Environmental Protection, University of Silesia, \\ Bankowa 9, 40-007 Katowice, Poland \\ ${ }^{2}$ Department of Geobotany and Nature Protection, Faculty of Biology and Environmental Protection, \\ University of Silesia, Jagiellońska 28, 40-032 Katowice, Poland \\ ${ }^{3}$ Department of Ecosozology, Faculty of Natural Sciences, Comenius University, Mlynská dolina, \\ 84215 Bratislava, Slovakia
}

(Received: 4 March 2008; accepted: 6 June 2008)

\begin{abstract}
In the area of the Moravian Gate at Štramberk (Moravia, Czech Republic) detailed field investigations of Thysanoptera were conducted. The Gate offers the possibility of dispersal of thrips species from the South to the North and vice versa. A total of 359 samples were collected, from which 2367 adult specimens of Thysanoptera belonging to 55 species were obtained. Between them are species having their main distribution in the Southern parts of Europe, such as Aptinothrips elegans, Anaphothrips atroapterus, A. euphorbiae, Chirothrips aculeatus, Limothrips consimilis, Neohydatothrips abnormis, Rubiothrips pillichi, R. validus and Theilopedothrips pilosus. Additionally species were found that are absent or dispersed in Southern Europe, such as Aptinothrips stylifer, Chirothrips hamatus, Odontothrips loti and Platythrips tunicatus. In ancient times these species may have used the Moravian Gate, which has been passed by large armies and many traders (the amber route), carrying all kinds of plant products with them.
\end{abstract}

Keywords: thrips, Thysanoptera, Štramberk, the Czech Republic, Moravian Gate.

Dispersal of insects, including representatives of the Thysanoptera, to new areas is a complex process. In Central Europe spreading of thrips has been connected for thousands of years with wars and food trade.

In all likelihood (Moritz, 2006), the expansion of certain thrips species (e.g. Thrips tabaci Lindeman) was facilitated by transportation of food supplies (fruit, vegetables, onion, garlic) by Roman legions during their expeditions. Geographical barriers, e.g. the Pyrenees and the Alps, were crossed by the Carthaginian army commanded by Hannibal. The large number of wars that took place during the last two thousand years not only made it easier for plagues and diseases to spread, but also offered a chance for thrips to move to new territories. Equally important for this process were the ancient trade routes, e.g. the amber route, silk route and incense route. Trade guilds like Hansa, which exchanged goods between the Eastern and Western Europe, also contributed for centuries to the spreading of thrips. Especially the Amber Route and the Silk Route played a very important role in this process. As one of the waterways and ancient highways, for centuries the road led from Europe to Asia and back, and from northern Europe to the Mediterranean. In Roman times, a main route ran south from the Baltic coast in Prussia through the land of the Boii (modern

\footnotetext{
* Corresponding author; e-mail: wojciech.sierka@gmail.com
} 
Bohemia) to the head of the Adriatic Sea. The Egyptian pharaoh Tutankhamun had Baltic amber among his burial goods, and amber was sent from the North Sea to the temple of Apollo at Delphi as an offering. From the Black Sea, trade could continue to Asia along the Silk Road, another ancient trade route.

The problem of migration of thrips is extremely interesting, especially nowadays. Thysanoptera are important factors in the global economy and their presence in agrocenoses is often highly detrimental. The globalisation of the economy and transportation of food on a global scale have enabled some thrips species to penetrate new environments. Dangers involved in this process have resulted in some species being placed on European quarantine lists (e.g. Thrips palmi Karny) (Loomans and Vierbergen, 1997). Moreover, the process of colonisation of new areas by particular species still remains obscure, as do the precise route of migration and the genesis of particular thysanopterofaunas.

From ancient times, the Moravian Gate formed a natural pass between the Sudetes and the Carpathians and it is an important ecological corridor on a European scale (Parusel, 1997). It forms a depression between the Western Carpathians and the Eastern Sudetes, and the watershed between the upper Odra and Bečva rivers. It stretches from Moravia north-eastward, towards Silesia, for about $65 \mathrm{~km}$. It is bordered by the confluence of the Olza and Odra rivers in the north (Gacka-Grześkiewicz, 1995). Here ran the most important trade routes from southern Europe to the Baltic Sea (e.g. the Amber Road), and also routes from Lesser Poland to Czech lands. The Gate may have played a vital role in the expansion of thrips within and through this area. The role of the Moravian Gate manifests itself in various ways. Some of them are listed below:

- the area where plants and animals from the Sudeten Mts and the Carpathian Mts come in touch and spread, e.g. to the upland and lowland areas of Poland (Szafer, 1977; Zając, 1996),

- the area through which taxa from the South can migrate to the North, to Poland (and farther) and into the interior of the Czech Republic,

- the area through which colonial cultures with thrips can move from the North to the South, e.g. Limothrips denticornis Haliday, L. cerealium Haliday and Thrips tabaci. The aim of this study is to detect species of Thysanoptera in the area of the Moravian Gate in the Czech Republic, which may have passed trough the Gate to the North or to the South in ancient times.

\section{Materials and Methods}

\section{Study area}

The area of investigation is located in the neighborhood of the Moravian Gate, (Moravia, the Czech Republic), more specifically at Stramberk. This is a small mountain town in the middle of the Štramberská vrchovina (Highland), stretching across slopes of Zámecký kopec, Kotouč, Bílá hora, Libotínské vrchy and Červený kámen, along the foothills of the Beskydy Mts., called "Moravian Bethlehem" for its picturesqueness. 


\section{Collecting and identification}

This study was conducted during several stays in Štramberk (spring 2005, summer and autumn 2006). Insects were collected within the entire area around the town in plots of varying habitats, with an entomological sweep net. Moreover, flower feeding and leaf feeding species were collected over the entire area by shaking plants over a plastic tray, with the help of a sack, or by placing selected shoots in sacks and collecting insects which left the withering plant material.

Thrips were stored in AGA fluid. For mounting thrips on slides the Bisevac (1997) method was used. Specimens were identified on the basis of Schliephake and Klimt (1979) as well as zur Strassen (2003). The specimens are stored in the Department of Zoology, University of Silesia, Poland.

\section{Results}

A total of 359 samples were collected, from which 2367 adult specimens of Thysanoptera were obtained - 1484 of the family Thripidae and 883 of the family Phlaeothripidae. From the qualitative point of view, they were classified as 55 species (49 of Thripidae and 6 of Phlaeothripidae, Table 1). This makes up a large part of the total number of species thrips recorded from the Czech Republic (Pelikán, 1952, 1954, 1957, $1960,1961,1965)$. Because of geographical preferences and thermal profiles among recognized species, special attention should be devoted to thrips connected with dry places (distribution and host plant range after zur Strassen, 2003):

- Anaphothrips atroapterus Priesner - xerothermophilous, in dry areas, on dry sprouts of species of Euphorbia, especially E. cyparissias and E. gerardiana. At Štramberk on E. cyparissias and Bromus ramosus.

- Anaphothrips euphorbiae Uzel - xerothermophilous, in Central Europe only on warm islands, on various Euphorbia spp., especially E. amygdaloides, E. cyparissias and E. esula. At Štramberk on Euphorbia cyparissias.

- Aptinothrips elegans Priesner - Ponto-Mediterranean, also in areas with mild climate in Central Europe, also in South Sweden and South Norway; thermophilous, on various species of grass (Poaceae). At Štramberk on Euphorbia virgata and Ononis arvensis.

- Chirothrips aculeatus Bagnall - West Palaearctic; thermophilous, on various grasses, especially Avena, many species of Bromus and on Lolium. At Štramberk on Bromus squarosus, Poa crassipes and Lolium temulentum.

- Limothrips consimilis Priesner - Eurosiberian; xerophilous and thermophilous, graminicolous, on various grasses, especially on Bromus erectus. At Štramberk on Inula alicina, Bromus erectus and Ononis arvensis.

- Neohydatothrips abnormis (Karny) - European, in xerothermophilous places; on Astragalus and other Fabaceae. At Štramberk on Genista tinctoria, Astragalus onobrychis and Antylis vulneraria. 


\section{Table 1}

List of thrips species collected at Štramberk (Moravia, Czech Republic) in the area of the Moravian Gate

Aeolothripidae
Aeolothrips albicinctus Haliday
Aeolothrips ericae Bagnall
Aeolothrips fasciatus (Linnaeus)
Aeolothrips intermedius Bagnall
Aeolothrips versicolor Uzel
Aeolothrips vittatus Haliday
Thripidae

Anaphothrips atroapterus Priesner

Anaphothrips euphorbiae Uzel

Anaphothrips obscurus (Müller)

Aptinothrips elegans Priesner

Aptinothrips rufus Haliday

Aptinothrips stylifer Trybom

Baliothrips dispar (Haliday)

Bolacothrips jordani Uzel

Chirothrips aculeatus Bagnall

Chirothrips hamatus Bagnall

Chirothrips manicatus Haliday

Dendrothrips degeeri Uzel

Dendrothrips saltatrix Uzel

Frankliniella intonsa (Trybom)

Frankliniella occidentalis (Pergande)

Iridothrips iridis (Watson)

Limothrips cerealium Haliday

Limothrips consimilis Priesner

Limothrips denticornis Haliday

Neohydatothrips abnormis (Karny)

Neohydatothrips gracilicornis (Williams)
Odontothrips confusus Priesner

Odontothrips loti (Haliday)

Odontothrips phaleratus (Haliday)

Oxythrips ajugae Uzel

Oxythrips bicolor (Reuter)

Pezothrips dianthi (Priesner)

Platythrips tunicatus (Haliday)

Rubiothrips ferrugineus (Uzel)

Rubiothrips pillichi (Priesner)

Rubiothrips validus Karny

Stenothrips graminum Uzel

Theilopedothrips pilosus (Uzel)

Thrips angusticeps Uzel

Thrips atratus Priesner

Thrips euphorbiae Knechtel

Thrips flavus Schrank

Thrips fuscipennis Haliday

Thrips major Uzel

Thrips physapus Linnaeus

Thrips tabaci Lindeman

Thrips trehernei Priesner

Thrips validus Uzel

\section{Phlaeothripidae}

Haplothrips acanthoscelis Karny

Haplothrips aculeatus (Fabricius)

Haplothrips dianthinus Priesner

Haplothrips leucanthemi (Schrank)

Haplothrips setiger Priesner

Hoplandrothrips williamsianus Priesner

- Rubiothrips pillichi (Priesner) - thermophilous, mainly on Galium glaucum, also G. odoratum and G. silvaticum. In Štramberk on Galium verum and Knautia dipsacifolia.

- Rubiothrips validus Karny - thermophilous, on Galium odoratum, G. palustre and G. silvaticum. At Štramberk on Galium spurium and Campanula moravica. 
- Theilopedothrips pilosus (Uzel) - European; thermophilous, in grassy areas, semidry and dry grasses. In Štramberk on Trifolium arvense, T. fragiferum and Vicia dumetorum.

Apart from the above-mentioned species, it is worth noting some species that are absent in Southern Europe (distribution and host plant range after zur Strassen, 2003):

- Aptinothrips stylifer Trybom - Holarctic species, particularly in moderate latitudes, to an altitude of $3800 \mathrm{~m}$, originally Palaearctic, introduced several times into other continents; sciophilous, on many grasses (Poaceae). In the study area on Alopecurus pratensis.

- Chirothrips hamatus Bagnall - European (excluding Southern part), introduced into Northern America; usually in moist places, particularly on Alopecurus pratensis. At Štramberk on Bromus squarrosus.

- Odontothrips loti (Haliday) - Palaearctic (except the Southern parts), introduced into North America, polyphagous on many Fabaceae, with preference for Anthyllis, Coronilla, Genista, Lotus, Ononis and Trifolium. In the study area on Trifolium fragiferum.

- Platythrips tunicatus (Haliday) - European (except the Southern part), grassy areas and meadows, on various species of Galium, especially G. mollugo. At Štramberk on Galium spurium and Lunaria rediviva.

\section{Discussion and Conclusions}

Migration of thrips is connected with individual dispersal and the effective dynamics of particular populations. Characteristic patterns of occurrence depend on the relative position of organisms, which can be single, relatively accidental (e.g. L. denticornis), regular (e.g. mass outbreaks of T. tabaci on crops of the cucumber in the glasshouse), or aggregational (e.g. Suocerathrips linguis Mound and Marullo) (Moritz, 2006).

In the area of Štramberk, a botanic garden and arboretum are situated on the southern slope of the former limestone pit called Dolní Kamenárka. Calcicole and thermophilous plants represent a major portion of the garden. The bottom part of the garden is occupied by a unique limestone fen abundant in water- and swamp-plants. Species classified as hygrophilous thrips were reported, e.g. C. hamatus, Baliothrips dispar (Haliday) and Iridothrips iridis (Watson).

The intensified European internal and external exchange of products, among others tobacco and potatoes, coincided with the gradual discovery of the New World. Gigantic forwarding airplanes for the global transfer of plants resulted in phenomena defined as insect invasion, e.g. of Frankliniella occidentalis (Pergande). Within the space of about 25 years $F$. occidentalis, also found in the study material, became a megastar among thrips, with the highest number of web pages on the internet of all thrips species. Passive spread and active dispersal are practically inseparable among thrips, mainly because aerial turbulence and strong winds make the transfer of insects possible across hundreds to thousands 
of kilometers. In the material of the Alpine fauna, Pelikán (1996) found 35 species of thrips at altitudes above 1850 m, 24 - above 2000 m, and two wingless species of Aptinothrips above $3000 \mathrm{~m}$. In reference to some species of thrips (e.g. Hoplandrothrips williamsianus Priesner) the term aerial plankton is used (Schliephake and Klimt, 1979). The size and the position of the Moravian Gate influence the local circulation of air masses and allow thrips to become part of the aerial plankton, so it should not be surprising that $H$. williamsianus was reported from this study.

Further research conducted with different sampling methods may produce information about other species inhabiting the vicinity of the Moravian Gate.

\section{Acknowledgement}

The authors thank Dr. P. Pavlik from Štramberk for inspiration as well as the use of his quarry.

\section{Literature}

Bisevac, L. (1997): A new method for mounting thrips (Thysanoptera) on slides. Austr. J. Entomol. 36, 220.

Gacka-Grześkiewicz, E. (1995): Korytarz ekologiczny doliny Wisły. Stan, funkcjonowanie, zagrożenia. Fundacja IUCN Poland, Warszawa, pp. 278.

Loomans, A. J. M. and Vierbergen, G. (1997): Thrips palmi. A next thrips pest in line to be introduced into Europe? - Bulletin IOBC/WPRS 20, 162-168.

Moritz, G. (2006): Thripse - Fransenflügler, Thysanoptera. Westarp-Wiss. pp. 384.

Parusel, J.B. (1997): Brama Morawska - biogeograficzne aspekty badawcze. In: A. T. Jankowski (ed.): Brama Morawska - aspekty badawcze i turystyczne. University of Silesia, Katowice, pp. 85-89.

Pelikán, J. (1952): Přehled tř́snokřídlých z Československa. Entomol. Listy 15, 185-195.

Pelikán, J. (1954): Nové nálezy třásnokřídlých z ČSR. Zool. Entomol. Listy 17, 202.

Pelikán, J. (1957): Řád tř́ásnokřídli - Thysanoptera. In: J. Kratochvíl (eds): Klíč zviŕreny ČSR. Vol 2. ČSAV, Praha, pp. 9-34.

Pelikán, J. (1960): Neue Thysanopterenarten aus der Tschechoslowakei - III. Čas. Čs. Spol. Entomol. 57, $112-117$.

Pelikán, J. (1961): New species of Thysanoptera from Czechoslovakia - IV. Acta Soc. Entomol. Čechoslov. 58, $60-70$.

Pelikán, J. (1965): New species of Thysanoptera from Czechoslovakia - V. Acta Soc. Entomol. Čechoslov. 62 , 98-104.

Pelikán, J. (1996): Vertical distribution of alpine Thysanoptera. Fol. Entomol. Hung. 57, 121-125.

Schliephake, G. and Klimt, K. (1979): Thysanoptera. Die Tierwelt Deutschlands. Gustav Fisher Verlag, Jena, pp. 477.

Strassen, R. zur (2003): Die Terebranten Thysanopteren Europas und des Mittelmeer-Gebietes. Goecke and Evers, Keltern, pp. 277.

Szafer, W. (1977): Szata roślinna Polski niżowej. In: W. Szafer and K. Zarzycki (eds): Szata Roślinna Polski, PWN, Warszawa, pp. 177-188.

Zając, M. (1996): Mountain vascular plants in the Polish lowlands. Pol. Bot. Stud. 11, p. 230. 